\title{
MOTIVATION AS AN INTERVENING VARIABLES INFLUENCE COMPETENCY ON THE PERFORMANCE OF COOPERATIVE MANAGERS
}

\author{
Eko Nur Fu'ad ${ }^{1}$, Moch. Aminnudin² \\ ${ }^{1,2}$ Faculty of Economics and Business, Universitas Islam Nahdlatul Ulama Jepara, Indonesia \\ e-mails: ${ }^{1}$ ekonfuad@unisnu.ac.id; ${ }^{2}$ amin2udin@gmail.com \\ Received December 30, 2020; accepted January 15, 2021; published January 29, 2021.
}

\begin{abstract}
Objective: This paper discussed the importance of competence and work motivation, and analysed the effect of these two variables on performance. Research Design \& Methods: This research sought to understand more about the manager's performance of microfinance institutions (cooperatives), so the selected sample was cooperative managers. The data collected from 88 questionnaires were analysed using PLS-SEM with SMART-PLS software. Findings: Competence has a significant effect on motivation and manager performance, motivation has a significant effect on performance, motivation as an intervening variable on the effect of competence on performance. Implications $\boldsymbol{\&}$ Recommendations: Work motivation is a more influential factor than competence on performance, so the activity that must be done to improve performance is to improve work motivation. Subsequent research carried out in other industries or with a larger sample size for generalization purposes. Contribution \& Value Added: The main contribution of this research is that to increase work motivation, it can be done by requiring employees to always improve their past performance for the better.
\end{abstract}

Keywords: competence; motivation; performance; manager; cooperatives.

JEL codes: D22, J24, M54,

Article type: research paper

\section{INTRODUCTION}

The development effort for cooperative business entities is inseparable from changes in the increasingly dynamic environment. In the era of globalization, which we have entered into with the implementation of the ASEAN Free Trade Area (AFTA) in China in January 2010, directing all business entities to global competition. Various world economic institutions have been forced to take part in the struggles within it, including in this case, of course, this applies to cooperative business entities that are mostly engaged in by economic enterprises in Indonesia. Apart from being a challenge, it is also a very strategic opportunity where cooperatives can play a role in it. The cooperative operates primarily to provide benefits to members through transactions and through the distribution of patronage income from these transactions. In order to play a significant role, cooperatives must grow and develop as competitive business institutions (Zivkovic \& Hudson, 2015).

The cooperative business model creates unique challenges that encourage economists to recognize the challenges, critical issues and success factors of cooperatives (Kenkel \& Park, 2011). As an organization or business entity engaged in the economic sector, cooperatives are one of the places for people's activities that are deemed appropriate to develop the people's economy, especially the people of the lower middle class. This is reasonable, because cooperatives can be established with relatively small capital in accordance with the economic conditions of the lower (poor) and middle class. Every member of the small society can "take part" in cooperatives according to their economic capacity. 
Several economic-cooperative figures said that cooperatives are the most suitable place for economic activities for middle to lower class people.

The dynamic development of a market economy, the impact of globalization, and the emergence of a welfare crisis, has resulted in an increasing number of poor people, especially in developing countries. Cooperatives are seen as capable of solving increasing social problems. Cooperatives can be an alternative to profit-oriented commercial economic entities (Czternasty, 2014).

Ironically, the hope that cooperatives as a solution to solve social problems is not accompanied by appropriate cooperative performance. Cooperatives are seen as unable to carry out their roles in accordance with government expectations. There are many problems and challenges faced by cooperatives in order to build and develop cooperative organizations and businesses to meet expectations. In an effort to achieve cooperative goals, the role of the manager as manager of the cooperative is related to the success of the cooperative in running its business. Managers have the responsibility and obligation to develop cooperatives as efficient economic/ business institutions, as well as support members' business activities efficiently by improving service quality.

With regard to manager performance, experts also argue that manager performance is influenced by intrinsic factors of the manager himself, such as his ability to manage organizational business and his motivation to become a cooperative manager. The intrinsic factor that can affect performance is a person's competence or ability to do the job. Several studies have shown the influence of competency on performance. There is a positive relationship between competencies and individual performance (Zaim et al., 2013). Improving employee performance can be done through individual competence and achievement motivation (Subari \& Riady, 2015). The higher the employees competence with more real results on improving the performance of employees (Renyut et al., 2017). The ability gives indirect influence on competence variables to employee performance and motivation variables to employee performance (Kurniawan et al., 2018). Competency is able to improve the performance (Irvan \& Heryanto, 2019). The ability of employees will create superior performance (Zafar et al., 2020).

Several studies have shown the influence of motivation on performance. Human performance in any form is enhanced by increased motivation (Muogbo, 2013). Likewise, motivation and its factors have a significant influence on employee performance (Azar \& Shafighi, 2013). Motivation plays a vital role toward the performance of employees (Zameer et al., 2014). The positive influence of motivation on employee performance is also shown by research (Dharma, 2017). When employees are motivated, they will improve their performance standards (Nabi et al., 2017). Another study show that the better the motivation possessed by employees, the more performance increases (Adam \& Kamase, 2019). The higher the level of work motivation possessed by the employees, the higher the level of employee performance (Suryani et al., 2020). To increase job performance it is important for policymakers to increase employees' work motivation (Susilo, 2020). The direct effect of the competency variable on employee performance shows smaller results than the indirect effect through the motivation variable, meaning that motivation is not an intervening variable (Parashakti et al., 2020).

Based on previous research, it was stated that competence and motivation greatly affect employee performance. Therefore, the purpose of this study is to determine the effect of these two variables (competence and motivation) on manager performance. In addition, this study aims to determine the extent to which competence can increase the level of motivation of managers, so as to improve their performance.

\section{LITERATURE REVIEW}

\section{Performance}

Managerial performance is defined as the performance of individual members of the organization in managerial activities, including planning, investigation, coordination, supervision, staffing, negotiation and representation (Wibowo, 2013). Meanwhile Umar (2005) defines managerial performance as the work that can be achieved by a leader in an organization. Individual members of the organization who 
play a role in carrying out managerial functions, one of which is the manager, this is based on the fact that the nature of the work of managers is often uncertain and unclear which demands managers to improvise to set goals in achieving organizational goals. In order to carry out managerial activities, managers must carry out managerial activities, including: planning, investigation, coordination, supervision, staffing, negotiation and representation (Gomez-Mejia \& Cardy, 2011).

The task of evaluating managerial performance is an important function in an organization. Programming and developing a budget system are critical steps in planning organizational activities, be it corporate, social, governmental organizations or on an individual scale (Zainal et al., 2014).

According to Vroom in Greene (2003), the extent to which a person's success in completing his job is called the "level of performance". Usually, people with a high level of performance are called productive people, and on the other hand, people with levels that do not reach the standard are said to be unproductive or underperforming.

Performance can also be interpreted as the extent to which a person carries out his responsibilities and work duties (Singh \& Loncar, 2010). Job performance is a record of the results or outputs (outcomes) resulting from a specific job function or activity within a certain period of time. Meanwhile, performance measurement according to is a way to measure the level of individual contribution to the organization (Gomez-Mejia \& Cardy, 2011).

Performance is measured by instruments developed in studies that are incorporated into general performance measures, which are then translated into basic behavioural assessments, including: quantity of work, quality of work, knowledge of work, opinions or statements expressed, work planning (Gibson \& Donnely, 1995). According to Robbins (2012), namely: quantity of work, quality of work, efficiency and professionalism.

\section{Competence}

Competence or ability is defined as an inherent characteristic of a person related to the implementation of a job effectively or very successfully (and underlying characteristics: of individual which is casually related to effective or superior performance in job) (Gilboa et al., 2008). It is this inequality in these competencies that distinguishes a superior actor from the behaviour of an average achiever. To achieve moderate or average performance requires threshold competencies or essential competencies. Boundary competencies or special competencies for a particular job are patterns or guidelines in employee selection (personnel selection), task transfer planning (succession planning), performance appraisal (performance appraisal), and development (development).

Competence is defined Zainal et al. (2014) as the underlying characteristics of an individual which is causally related to criterion-referenced effective and or superior performance in a job or situation. Or characteristics that underlie a person and are related to the effectiveness of individual performance in their work.

Based on this understanding, the competence of an individual is something inherent in him that can be used to predict his level of performance. Something that is meant can be related to motives, selfconcept, characteristics, knowledge and abilities/ expertise. Individual competences in the form of abilities and knowledge can be developed through education and training. While the competence motive can be obtained during the selection process.

Competence is divided into two categories, namely "threshold competencies" and "differentiating competencies". Threshold competencies are the main characteristics a person must have in order to carry out his job. But not to distinguish a high performer and an average person. Meanwhile "differentiating competencies" are the factors that differentiate high and low performers (Zainal et al., 2014).

Competence can be in the form of goals, temperament, self-concept, attitudes or values, problem mastery, or cognitive skills or behavioural skills. Each individual trait that can be measured or calculated clearly and can be shown to clearly distinguish between people behaving superiorly and 
people behaving on average, or people behaving effectively and people behaving ineffectively (Handoko, 2010).

Robert \& Jackson (2001) illustrated that competence is visible and there is hidden. Knowledge is more visible, recognizable by companies to match people to jobs. Although some of the skills can be seen, some are less identified. However, hidden competencies in the form of skills that may be more valuable can improve performance.

Organizations must pay attention to the competencies of their employees to achieve their goals (Priyono et al., 2016). Competencies can be identified by the existence of three types of basic skills, namely Katz (2009): 1) Technical skills, namely, the human ability to use procedures, techniques and knowledge of special fields; 2) Human skills, namely, the ability to work together, understand and motivate others as individuals or groups; 3 ) Conceptual skills, namely the ability to coordinate and integrate all the interests and activities of the organization, including seeing the organization as a whole, understanding how the parts are interdependent, and anticipating how changes in a part will affect the entire organization.

The HR competencies is needed to face new challenges and the types of organizations in the workplace can be obtained by understanding the characteristics we are looking for in the people who work in these organizations. The basic concept of competence standards in terms of etymology, competence standards are open to two vocabularies, namely standards and competencies. Standard is defined as an agreed measure or standard, while competence is defined as the ability to carry out tasks in the workplace which includes applying skills which are supported by knowledge (cognitive) and abilities (abilities) in accordance with the conditions required. Thus, the competence standard can be assumed as a formulation of what abilities and skills the workforce (HR) must have in carrying out work in accordance with the stipulated / agreed requirements.

Competence is closely related to performance, both individual performance and organizational performance (company). According to ArmstrongKogan (2001) a person's performance is based on understanding the knowledge, skills, skills and behaviours needed to do a job well. While the performance of the organization (company) is based on how the company's management responds to external and internal conditions, with certain benchmarks it will be possible to know the level of turbulence and the level of ability to anticipate.

HR competence analysis is intended to produce a profile or model that is used to: 1) Individual performance management; 2) Acceptance or placement; 3) Career development. Some of the criteria that can be analysed include: individual drive (motivation to succeed), impact and results, analytical power, strategic thinking, creative thinking (ability to innovate), assertiveness in making decisions, commercial assessment, management and leadership teams, interpersonal relationships. communication skills, ability to adapt and cope with changes and pressures, ability to plan and control projects.

Competence analysis can also describe a person's nature by assessing knowledge, specific skills required, education, training and experience. There are several competence analysis techniques that can be used, among others Kadarisman (2011): 1) Critical incident (critical incident), which is used to collect and obtain data about effective or less effective behaviour, then linked to actual critical events; 2) Repertory grid analysis, is used to identify dimensions that differentiate people who have good performance from people who have less / standard performance; 3) Job competence assessment (job competence assessment).

Several studies have shown the influence of competency on performance. There is a positive relationship between competencies and individual performance (Zaim et al., 2013). Improving employee performance can be done through individual competence and achievement motivation (Subari \& Riady, 2015). The higher the employees competence with more real results on improving the performance of employees (Renyut et al., 2017). The ability gives indirect influence on competence variables to employee performance and motivation variables to employee performance 
(Kurniawan et al., 2018). Competency is able to improve the performance (Irvan \& Heryanto, 2019). The ability of employees will create superior performance (Zafar et al., 2020).

H1: Competence has influence on motivation

$\mathrm{H} 2$ : Competence has influence on job performance

\section{Work Motivation}

Motivation refers to the forces either within or external to a person that arouse enthusiasm and persistence to pursue a certain course of action. The importance of motivation is that it can lead to behaviours that reflect high performance within organizations. Managers can use motivation theory to help satisfy employees' needs and simultaneously encourage high work performance (Daft, 2008).

Motivation is a complex problem in organizations, because the needs and desires of each member of the organization are different from one another. This is different because each member of an organization is biologically and psychologically unique, and develops on the basis of different learning processes.

Motivation is also defined as a set of forces that cause people to behave in certain ways (Griffin, 2012). To find out more about the problem of motivation, here are some definitions of motivation. Motivation can be interpreted and interpreted differently by each person according to the place and situation of each person and adapted to the development of human civilization. Thus, etymologically, motivation is related to the things that encourage or move someone to do something. Steers \& Porter (1998) in Mangkunegara (2015) expressed the following opinion about motivation: Motivation is a general term applying to the entire class of drives, desire, needs, wishes and similar forces. To say that managers motivate their subordinates is to say that they do those things which they hope will satisfy these drives and desires and induce the subordinates to act in a desired manner (Motivation is a general definition that uses the whole class of motivation, wants, needs, expectations and similar forces. To say that managers motivate their subordinates is to say that they do the things they hope will satisfy these urges and desires and encourage subordinates to act in a desired way).

Abraham Sperling (1987) in Mangkunegara (2015) argues that motive is defined as a tendency to do activity, starting from a drive in oneself (drive) and ending with adjustment. Meanwhile, Stanton in Mangkunegara (2015) defined that motive is a stimulated need that is oriented towards individual goals in achieving satisfaction. Motivation is defined by Stanford in Mangkunegara (2015) that motivation is a condition that moves humans towards a specific goal.

Based on the opinions of the experts above, it can be concluded that the motive is an impetus for the needs of employees that need to be met so that the employee can adapt to his environment, while motivation is a condition that moves employees to be able to achieve the goals of their motives. Meanwhile, motivation is said to be the energy to generate drive arousal. In relation to the work environment, Abraham Sperling (1987) in Mangkunegara (2015) argued that work motivation is defined as a condition that influences to generate, direct and maintain behaviour related to the work environment.

The main benefit of motivation is to create work passion, so that work productivity increases. Meanwhile, the benefit that comes from working with motivated people is that the job gets done properly. This means that work is completed according to the correct standards and within a predetermined time scale, and people like to do their work. Something that is done because there is motivation that drives it will make people happy to do it. People will feel appreciated / recognized, this happens because their work is truly valuable for motivated people, so that person will work hard. This is understandable because the motivation is so high to produce according to the targets they set. Its performance will be monitored by the individual concerned and will not require too much supervision and morale will be high (Arep \& Tanjung, 2003).

Herzberg (1966) in Arep \& Tanjung (2003) developed Maslow's hierarchy of needs theory into a twofactor theory of motivation. These two factors are called the motivation factor which is called intrinsic motivation and the maintenance factor which is called extrinsic motivation. 
Satisfaction factors which are also called motivators, which are the driving factors for a person to achieve that originates from within a person (intrinsic condition), among others: achievement; recognition of others (recognition); responsibility; opportunities for advancement; possible career development (the possibility of growth).

Meanwhile, the maintenance factor, also known as the hygiene factor, is a factor related to fulfilling the need to maintain the existence of employees as human beings, maintaining peace and health. This factor is also called a dissatisfier (source of dissatisfaction) which is where the fulfilment of low-level needs that qualify into extrinsic factors, including: compensation; work security and safety; working conditions; status; company procedures; the quality of technical supervision of interpersonal relationships among peers, with superiors, and with subordinates.

Several studies have shown the influence of motivation on performance. Human performance in any form is enhanced by increased motivation (Muogbo, 2013). Likewise, motivation and its factors have a significant influence on employee performance (Azar \& Shafighi, 2013). Motivation plays a vital role toward the performance of employees (Zameer et al., 2014). The positive influence of motivation on employee performance is also shown by research (Dharma, 2017). When employees are motivated, they will improve their performance standards (Nabi et al., 2017). Another study show that the better the motivation possessed by employees, the more performance increases (Adam \& Kamase, 2019). The higher the level of work motivation possessed by the employees, the higher the level of employee performance (Suryani et al., 2020). To increase job performance it is important for policymakers to increase employees' work motivation (Susilo, 2020). The direct effect of the competency variable on employee performance shows smaller results than the indirect effect through the motivation variable, meaning that motivation is not an intervening variable (Parashakti et al., 2020).

H3: Motivation has influence on job performance

$\mathrm{H} 4$ : Motivation as an intervening variabel influences the competence on performance

\section{METHODS}

Based on the literature review, a theoretical framework is prepared which diagrammatically describes the flow of thought developed in this study. The theoretical framework in this study explained the direct relationship between the independent variables of competence and work motivation on manager performance as the dependent variable and manager performance on cooperative performance.

This type of research was descriptive analysis, which was a study of problems in the form of current facts in cooperatives in Jepara Regency. This study tests hypotheses or answers questions related to the current status of the object under study related to opinions, events or procedures in the form of relationships between competence variables, work motivation, and performance of cooperative managers in Jepara Regency.

This study used primary data derived from questionnaires distributed to cooperative managers in Jepara Regency to answer the formulation of research problems. Apart from primary data, secondary data was also needed which are obtained from the Cooperative Office of Jepara Regency in order to determine the sample area, sample size and work address of the respondent (cooperative manager).

The population chosen was the cooperative manager as the unit of analysis covering all cooperatives in Jepara Regency. Jepara Regency has 723 cooperatives spread across 16 (sixteen) districts.

In determining the sample, an appropriate sampling method was needed in order to obtain a representative sample and can describe the situation of the population optimally. Sampling using proportional sampling technique. Based on the calculation, the number of samples used was 88 cooperative managers.

Data analysis in this study was carried out using a structural equation model of Partial Least Square (PLS) 3.2.6. Partial Least Square (PLS) is a powerful analytical method because it does not assume that data must be measured in a specific way, can be applied to all data scales, does not require many assumptions and sample sizes (Ghozali \& Latan, 2015). 


\section{FINDING}

The validity test is carried out based on "Table 1. Loading Factors of Construct" which shows that all questionnaire items from all constructs were declared valid except for the Comp-1 item which has a value of 0.427 . In data processing, the indicator item was dropped because it has a low value which indicates that the item question was invalid.

Table 1. Loading Factors of Construct

\begin{tabular}{llcc}
\hline \multirow{2}{*}{ Latent variable } & \multicolumn{1}{c}{ Indicator } & $\begin{array}{c}\text { Loading } \\
\text { Factors } \\
\end{array}$ & Mean \\
& I have good skills in doing my job & 0.5 & \\
\hline & I can develop and use deep technical knowledge run my job & 0.427 & 4.40 \\
& I can absorb all the information related to organizational development & 0.660 & 4.28 \\
Competence & 0.757 & 4.30 \\
& I have enough abilities to take the initiative in organizational progress & 0.752 & 4.25 \\
& I am ready to carry out my duties in a timely manner and if I fail to accept & 0.779 & 4.35 \\
& sanctions & & \\
\hline & I always improve my past performance to achieve better current performance & 0.642 & 4.16 \\
& I always enjoy the difficult challenges of getting work done & 0.671 & 4.30 \\
Motivation & 0.751 & 4.11 \\
& I enjoy being responsible for the job at hand & 0.678 & 4.20 \\
& I always try to build close relationships with my colleagues at work & 0.752 & 4.00 \\
\hline & I always enjoy working with other people to get things done & 0.507 & 4.41 \\
& I was able to complete all work items (work quantity) as targeted & 0.780 & 4.34 \\
& The results of my work are in accordance with the established quality & & \\
& standards & 0.647 & 4.02 \\
Performance & & 0.726 & 3.98 \\
& My work has met the criteria for efficiency & & \\
\hline & I try to work professionally in accordance with what this organization & &
\end{tabular}

"Table 2. Reliability and Convergent Validity" showed that all the constructs used in this study were valid and reliable.

Table 2. Reliability and Convergent Validity

\begin{tabular}{lccc}
\hline & $\begin{array}{c}\text { Cronbach's } \\
\text { Alpha }\end{array}$ & $\begin{array}{c}\text { Composite } \\
\text { Reliability }\end{array}$ & $\begin{array}{c}\text { Average Variance } \\
\text { Extracted (AVE) }\end{array}$ \\
\hline Competence & 0.723 & 0.827 & 0.546 \\
Motivation & 0.743 & 0.827 & 0.490 \\
Performance & 0.591 & 0.764 & 0.452 \\
\hline
\end{tabular}

Source: Primary data processed

The validity test was carried out based on "Table 3. Discriminant Validity" showed that the model used was categorized as valid.

Table 3. Discriminant Validity

\begin{tabular}{lccc}
\hline & Competence & Motivation & Performance \\
\hline Competence & 0.739 & & \\
Motivation & 0.607 & 0.700 & \\
Performance & 0.486 & 0.563 & 0.673 \\
\hline Source: Primary data processed & &
\end{tabular}

Source: Primary data processed

Furthermore, based on "Table 4. Regression and Data Analysis" showed that all independent variables have a direct effect influence on manager performance with P-Values $<0.05$. 
Table 4. Path Coefficients

\begin{tabular}{lccc}
\hline & Original Sample & T Statistics & P Values \\
\hline Competence -> Motivation & 0.607 & 11.508 & 0.000 \\
Competence -> Performance & 0.229 & 2.001 & 0.046 \\
Motivation -> Performance & 0.424 & 3.941 & 0.000 \\
\hline $\mathrm{R}^{2}$ & 0.368 & 5.675 & 0.000 \\
Adjusted $\mathrm{R}^{2}$ & 0.350 & 4.446 & 0.000 \\
\hline
\end{tabular}

Source: Primary data processed

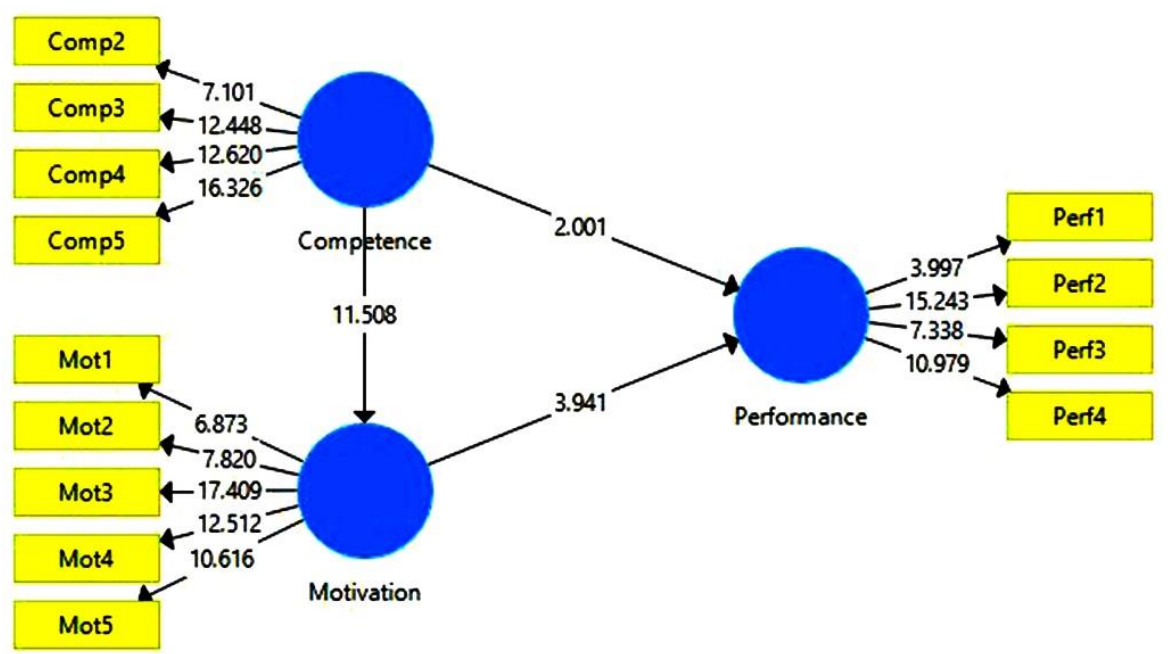

Figure 1. Output Result of Structural Model

Based on "Table 4. Path Coefficients" and "Table 5. Indirect Effects" showed that the indirect effect of competence on performance (3.624) was greater than the direct effect (2.001), so it can be interpreted that motivation was an intervening variable that influences competence on performance.

Table 5. Indirect Effects

\begin{tabular}{lccc} 
& Original Sample & T Statistics & P Values \\
\hline Competence -> Motivation & & & \\
Competence -> Performance & 0.257 & 3.624 & 0.000 \\
Motivation -> Performance & & & \\
\hline Source: Primary data processed & &
\end{tabular}

Source: Primary data processed

\section{Hypothesis Test Analysis}

The first hypothesis of this study was "Competence has significant effect on motivation". Based on the Path Coefficient table, it was known that the t-statistic value of 11.508 was greater than the t-table value of 1.988 ( $\mathrm{Sig} 0.000<0.05$ ). These results prove that the first hypothesis of this study was accepted. This means that competence has a significant effect on motivation.

The second hypothesis of this study was "Competence has significant effect on performance". Based on the Path Coefficient table, it was known that the t-statistic value of 2.001 was greater than the table value of 1.988 (Sig $0.049<0.05$ ). These results proved that the first hypothesis of this study was accepted. This means that competence has a significant effect on performance.

The third hypothesis of this study was "Motivation has significant effect on performance". Based on the Path Coefficient table, it was known that the t-statistic value of 3.941 was greater than the t-table value of 1.988 ( $\operatorname{Sig} 0.000<0.05$ ). These results proved that the first hypothesis of this study is accepted. This means that motivation has a significant effect on performance.

The fourth hypothesis of this study was "Motivation as an intervening variable influences the competence on performance". Based on the Path Coefficient and Indirect Effects table, it was known that the indirect effect of competence on performance (3.624) was greater than the its direct effect 
(2.001). These results proved that the fourth hypothesis of this study was accepted. It means that motivation as intervening variable influences the competence on performance.

\section{DISCUSSION}

Competence has a significant effect on motivation to be accepted as shown by the value of the tstatistic 11.508. The findings of this study support the results of the study which states that competence has a significant effect on motivation (Irvan \& Heryanto, 2019); (Parashakti et al., 2020). Competence is shown by always using and developing technicalities in carrying out work, trying to absorb all information related to organizational development, having the initiative to advance the organization, carrying out tasks in a timely manner, and readiness to receive sanctions if they fail to carry out tasks. If this is done continuously, especially competence in carrying out tasks on time and the consequences of receiving sanctions in the event of failure, then efforts to improve better performance by enjoying job responsibilities and challenges, as well as establishing cooperation by building relationships among colleagues in completing work to be better.

The second hypothesis of this study was accepted, as indicated by the t-table value of 2.001, that is competence has a significant effect on manager performance. The results of this study contradicted research findings Adam \& Kamase (2019) which state that competence does not have a significant effect on performance. However, the findings of this study support the statement that competence has a significant effect on performance (Zaim et al., 2013); (Renyut et al., 2017); (Kurniawan et al., 2018); (Zafar et al., 2020). Managers who have the competence shown by always using and developing technicalities in carrying out work, trying to absorb all information related to organizational development, have the initiative to advance the organization, carry out tasks in a timely manner, and readiness to receive sanctions if they fail to carry out their duties. The competence possessed by managers is not always related to capable skills in completing work, but competence in carrying out tasks on time. In addition, there are consequences of receiving sanctions in the event of failure, then these two things will be able to improve manager performance. Improved manager performance is indicated by the completion of all work items in the predetermined quality and quantity aspects. In addition, competent managers can work professionally and meet efficiency standards so that it has a good impact on cooperative institutions.

Motivation has a significant effect on accepted performance, as shown by the t-statistic value of 3.941. The findings of this study are different from the results of research (Muchtar, 2016) which stated that there is no significant effect between motivation and performance. However, the results of this study support the research conducted by Azar \& Shafighi (2013); Muogbo (2013); Zameer et al. (2014); Dharma (2017); Nabi et al. (2017); Kurniawan et al. (2018); Adam \& Kamase (2019); Parashakti et al. (2020); Suryani et al. (2020); Susilo (2020) which stated that motivation has a significant effect on performance. There is an increase in motivation, which is indicated by the desire to improve better performance by enjoying job responsibilities and challenges. Work motivation can also arise if there is cooperation by building relationships with colleagues in completing work for the better. All of this will have an impact on the increase in manager's performance which is indicated by the completion of all work items in the predetermined quality and quantity aspects. In addition, managers who have high motivation will be able to work professionally and meet efficiency standards so that cooperative institutions will benefit.

The fourth hypothesis of this study was also accepted, motivation as an intervening variable of the influence of competence on performance, as shown in the indirect effect of competence on performance (3.624) was greater than the direct effect of competence on performance (2.001). The findings of this study support the results of the study of Irvan \& Heryanto (2019) which stated that motivation as an intervening variable has a significant influence between competence and performance. These findings can be interpreted that the higher the competence of a manager can improve performance if they have high work motivation. Managers who have high competence are managers who are ready to carry out their duties in a timely manner and accept the consequences of sanctions in case of failure, therefore all work can be completed while still paying attention to the 
suitability of the quality and quantity that has been determined if the manager can enjoy the responsibilities and challenges of the work carried out.

\section{CONCLUSION}

Based on the analysis and discussion, it can be concluded that partially each independent variable are competence and motivation, has a significant effect on the performance of cooperative managers. Then from the results of the analysis it can also be proven that the motivation as an intervening variable, the motivation variable has an indirect effect on the competency variable on manager performance. This statement can be proven by the magnitude of the indirect effect (competence on performance) through motivation, which is identified as an intervening variable when compared to the direct effect of competence on manager performance.

These empirical findings provide evidence that the competence and work motivation of managers need to be improved by management or administrators to support the performance of cooperative managers. The practical impact of this study encourages managers to always complete tasks on time and be ready to accept sanctions in case of failure, managers can work professionally and meet efficiency standards so that it has a good impact on cooperatives. In addition, management or administrators must encourage managers to always improve past performance for the better, and accustom them to accept challenges that can spur managers to complete each job. The important point of this empirical finding is that managers' efforts to complete tasks on time will have an impact on improving performance even better if they always improve past performance.

\section{REFERENCES}

Adam, F., \& Kamase, J. (2019). The Effect Competence and Motivation to Satisfaction and Performance. International Journal of Scientific \& Technology Research, 8(03), 132-140. https://www.ijstr.org/research-paper-publishing.php?month=mar2019

Arep, I., \& Tanjung, H. (2003). Manajemen Motivasi. PT. Gramedia Widiasarana Indonesia.

ArmstrongKogan, M. (2001). A Handbook of Human Resource Management Practice (7th ed.). Emerald Group Publishing Limited. https://doi.org/https://doi.org/10.1108/ws.2001.07950dae.003

Azar, M., \& Shafighi, A. A. (2013). The Effect of Work Motivation on Employees' Job Performance (Case Study: Employees of Isfahan Islamic Revolution Housing Foundation). International Journal of Academic Research in Business and Social Sciences, 3(9), 432-445. https://doi.org/10.6007/IJARBSS/v3-i9/231

Czternasty, W. (2014). The Position of Cooperatives in the New Social Economy. Management, 18(1), 488-503. https://doi.org/10.2478/manment-2014-0036

Daft, R. L. (2008). Management, Eighth ed. In Wiley, New York. Thomson South-West.

Dharma, Y. (2017). The Effect of Work Motivation on the Employee Performance with Organization Citizenship Behavior as Intervening Variable at Bank Aceh Syariah. Emerald Reach Proceedings Series, 1, 7-12. https://doi.org/10.1108/978-1-78756-793-1-00065

Ghozali, I., \& Latan, H. (2015). Partial Least Squares Konsep, Teknik dan Aplikasi Menggunakan Program SmartPLS 3.0 untuk Penelitian Empiris (2nd ed.). Badan Penerbit Universitas Diponegoro.

Gibson, I., \& Donnely. (1995). Organisasi dan Manajemen. Erlangga.

Gilboa, S., Shirom, A., Fried, Y., \& Cooper, C. (2008). A Meta-Analysis of Work Demand Stressors and Job Performance: Examining Main and Moderating Effects. Personnel Psychology, 61, $227-$ 271.

Gomez-Mejia, B., \& Cardy. (2011). Managing Human Resources (Internatio). Prentice Hall International Inc.

Greene, W. H. (2003). Econometric Analysis. In P. Education (Ed.), Journal of the American Statistical Association (Vol. 97, Issue 457). Prentice Hall. https://doi.org/10.1198/jasa.2002.s458

Griffin, R. W. (2012). Management, Eleventh Edition. South-Western Cengage Learning.

Handoko. (2010). Manajemen Personalia \& Sumberdaya Manusia (kedua). BPFE UGM. 
Irvan, R. M., \& Heryanto. (2019). The Effect ff Competence and Workload on Motivation and Its Impact on The Performance of Civil Servants at The Regional Secretariat of The Regency of Dharmasraya. Archives of Business Research, 7(5), 134-142. https://doi.org/10.14738/abr.75.6461

Kadarisman, M. (2011). The Effect of Professionalism and Competence on The Performance of Regional Representatives Council. 18(1), 53-62.

Katz, R. L. (2009). Skills of An Effective Administrator. Harvard Business School Publishing Corporation.

https://books.google.co.id/books?hl=en\&lr=\&id=dGx3CgAAQBAJ\&oi=fnd\&pg=PA1\&dq=tech nical+conceptual+and+human+skills\&ots=Z2E-66_ke2\&sig=PdMX9KYuyS5U-

P8avoGe_M7bRtA\&redir_esc $=\mathrm{y} \# \mathrm{v}=$ onepage $\& \mathrm{q}=$ technical conceptual and human skills\&f $=\mathrm{false}$

Kenkel, P., \& Park, J. (2011). Theme Overview: Critical Issues for Agricultural Cooperatives. Choices, 26(3).

Kurniawan, D. A., Guswandi, \& Sodikin, A. (2018). Performance Through Employees Capabilitieson PT. Binasinar Amity. International Journal of Research Science \& Management, 5(5), 48-60. https://doi.org/10.5281/zenodo.1249804

Mangkunegara, A. P. (2015). Perencanaan dan Pengembangan Sumber Daya Manusia. Rafika Aditama.

Muchtar. (2016). The Influence of Motivation and Work Environment. Sinergi, 6(2), 27-40. https://doi.org/http://dx.doi.org/10.25139/sng.v6i2.80

Muogbo, U. S. (2013). The Influence of Motivation on Employees' Performance: A Study of Some Selected Firms in Anambra State. Afrrev Ijah, 2(3), 134-151.

Nabi, M. N., Islam, M. M., Dip, T. M., \& Al-Hossain, M. A. (2017). The Impact of Motivation on Employee Performances: A Case Study of Karmasangsthan Bank Limited, Bangladesh. International Journal of Business and Management Review, 5(4), 57-78.

Parashakti, R. D., Fahlevi, M., Ekhsan, M., \& Hadinata, A. (2020). The Influence of Work Environment and Competence on Motivation and Its Impact on Employee Performance in Health Sector. Advances in Economics, Business and Management Research, 135(Aicmbs 2019), 259267. https://doi.org/https://doi.org/10.2991/aebmr.k.200410.040

Priyono, Marzuki, \& Soesatyo, Y. (2016). Influence of Motivation and Discipline on The Performance of Employees (Studies on CV. Eastern Star Home in Surabaya). Journal of Global Economics, Management and Business Research, 5(3), 212-220.

Renyut, B. C., Modding, H. B., Bima, J., \& Sukmawati, S. (2017). The Effect of Organizational Commitment, Competence on Job Satisfaction and Employees Performance in Maluku Governor's Office. IOSR Journal of Business and Management (IOSR-JBM), 19(11), 18-29. https://doi.org/10.9790/487X-1911031829

Robbins. (2012). Perilaku Organisasi. Salemba Empat.

Robert, L. M., \& Jackson, J. H. (2001). Manajemen Sumber Daya Manusia. Penerbit Salemba Empat.

Singh, P., \& Loncar, N. (2010). Pay Satisfaction, Job Satisfaction and Turnover Intent. Industrial Relations, 65(3), 470-490.

Subari, S., \& Riady, H. (2015). Influence of Training, Competence and Motivation on Employee Performance, Moderated By Internal Communications. American Journal of Business and Management, 4(3), 133-145. https://doi.org/10.11634/216796061504678

Suryani, L., Lubis, A. R., \& Majid, M. S. A. (2020). Does Work Motivation Mediate the Effect of Organizational Culture and Justice on Employee Performance of the Public Works and Spatial Planning Does Work Motivation Mediate the Effect of Organizational Culture and Justice on Employee Performance of the Pub. Sumerianz Journal of Business Management and Marketing, 3(7), 78-86. https://www.sumerianz.com/?ic=journal-home\&journal=27\&info=archivedetail\&month $=07-2020 \&$ issue $=7 \&$ volume $=3$

Susilo, D. (2020). Revealing the Effect of Work-From-Home on Job Performance During the Covid19 Crisis: Empirical Evidence from Indonesia. The Journal of Contemporary Issues in Business and Government, 26(1), 23-40.

Umar, H. (2005). Riset Sumber Daya Manusia dalam Organisasi. PT. Gramedia Pustaka Utama.

Wibowo. (2013). Manajemen Kinerja (3rd ed.). Rajawali Pers. 
Zafar, T. S., Suarsa, A., Gadzali, S. S., Hadiansah, D., \& Rahayu, Y. N. (2020). How the Work Environment Affects Employee Competence and its impact on Employee Performance? Survey of the Ministry of Religion of Sukabumi Regency, West Java Province, Indonesia. International Journal on Emerging Technologies, 11(4), 148-151. https://www.researchtrend.net/ijet/current_issue_ijet.php?taxonomy-id=81\#

Zaim, H., Yaşar, M. F., \& Ünal, Ö. F. (2013). Analyzing the Effects of Individual Competencies on Performance: a Field Study in Services Industries in Turkey. Journal of Global Strategic Management, 7(2), 67-77. https://doi.org/10.20460/jgsm.2013715668

Zainal, V. R., Basalamah, S., \& Muhammad, N. (2014). Islamic Human Capital Management. Rajawali Pers.

Zameer, H., Ali, S., Nisar, W., \& Amir, M. (2014). The Impact of the Motivation on the Employee' ${ }^{{ }^{T} M_{S}}$ Performance in Beverage Industry of Pakistan. International Journal of Academic Research in Accounting, Finance and Management Sciences, 4(1), 293-298. https://doi.org/10.6007/ijarafms/v4-i1/630

Zivkovic, S., \& Hudson, D. (2015). Impact of Relationship Between Managers and Board of Directors on Performance of Agricultural Cooperatives. In Southern Agricultural Economics Association (SAEA) Annual Meeting (Vol. 151, Issue 806). 